\title{
ANALISIS PERILAKU PENUMPANG KA BANDARA MANGGARAI - SOETTA PADA MASA PANDEMI DAN PENGARUHNYA TERHADAP POLA PERJALANAN
}

\author{
Malvin', Dewi Linggasari' $^{2}$, dan Hokbyan Angkat ${ }^{3}$ \\ ${ }^{1}$ Program Studi Sarjana Teknik Sipil, Universitas Tarumanagara, Jl. Letjen S. Parman No.1 Jakarta \\ malvin.325160041@stu.untar.ac.id \\ ${ }^{2}$ Program Studi Sarjana Teknik Sipil, Universitas Tarumanagara, Jl. Letjen S. Parman No.1 Jakarta \\ dewil@ft.untar.ac.id \\ ${ }^{3}$ Program Studi Sarjana Teknik Sipil, Universitas Tarumanagara, Jl. Letjen S. Parman No.1 Jakarta \\ hokbyanr@dtt.untar.ac.id
}

\begin{abstract}
In the current era of globalization, transportation is a fundamental need for all human, to carry out daily displacement activities. The journey to the airport is one of the activities that occur every day but the heavy traffic in Jakarta, makes people leave early so that the airport train is presented by PT. Railink. But, during COVID-19 pandemic, all transportation experience restrictions to reduce the number positive of COVID-19, restrictions by limiting the number of passengers in all transportation so the risk of it's spread can be minimized. This affects community activities because all transportation implements health protocols so that community is difficult doing activities. This research was conducted to determine the behavior of airport train passengers towards health protocols implemented by the government, whether they are aware of the dangers of COVID-19 so they realize the importance of implementing health protocols outdoors. The data for research was obtained through questionnaire, then processed using normative and descriptive analysis methods. The results of this study concluded that the awareness of each passenger and officer at the station or train is the most important thing to remind each other in implementing health protocols and obeying to the regulation recommended by the government.
\end{abstract}

Keywords: Airport Trains; Covid-19 Pandemic; Health Protocols; Travel Patterns; Policy

\begin{abstract}
ABSTRAK
Pada era globalisasi seperti saat ini, transportasi merupakan kebutuhan yang mendasar bagi semua manusia, guna melakukan suatu kegiatan perpindahan sehari-hari. Perjalanan menuju ke bandara merupakan salah satu aktivitas yang terjadi setiap hari namun padatnya lalu lintas di Jakarta, membuat masyarakat berangkat lebih awal sehingga dihadirkan kereta api bandara oleh PT. Railink. Namun ditengah pandemi COVID-19 ini semua perjalanan transportasi mengalami pembatasan untuk mengurangi jumlah positif COVID-19, pembatasan yang dilakukan dengan cara membatasi jumlah penumpang di semua transportasi sehingga resiko penyebarannya dapat diminimalisir. Hal ini sangat mempengaruhi aktivitas masyarakat karena semua transportasi menerapkan protokol kesehatan sehingga masyarakat sulit melakukan aktivitas. Penelitian ini dilakukan untuk mengetahui perilaku dari para penumpang kereta api bandara terhadap protokol kesehatan yang diterapkan pemerintah, apakah mereka sadar akan bahaya COVID-19 sehingga menyadari pentingnya melaksanakan protokol kesehatan di luar ruangan. Data untuk penelitian didapatkan melalui kuesioner, lalu diolah menggunakan metode analisis normatif dan deskriptif. Dari hasil penelitian disimpulkan bahwa kesadaran masing-masing penumpang maupun petugas yang berada di stasiun maupun kereta merupakan hal yang terpenting untuk saling mengingatkan dalam melaksanakan protokol kesehatan dan patuh kepada peraturan yang dianjurkan pemerintah.
\end{abstract}

Kata kunci: Kereta Api Bandara; Pandemi COVID -19; Protokol Kesehatan; Pola Perjalanan; Kebijakan

\section{PENDAHULUAN}

Pada era globalisasi seperti saat ini, transportasi merupakan suatu kebutuhan yang mendasar bagi semua manusia, guna melakukan suatu kegiatan perpindahan sehari-hari. Mayoritas masyarakat berharap ada efesiensi waktu, dan biaya dalam beraktifitas sehari-hari. Hal ini perlu didukung oleh sebuah moda transportasi yang bisa memberikan pelayanan sesuai dengan keinginan masyarakat. 
PT. Railink yang merupakan hasil kerja sama (joint venture) antara dua BUMN, yaitu PT Kereta Api Indonesia dan PT Angkasa Pura II dimana kedua-duanya merupakan Persero. PT. Railink menghadirkan layanan kereta bandara yang diberi nama Airport Railink Services (Layanan Bandara Railink) yang disingkat ARS. Kelebihan yang ditonjolkan dari ARS adalah ketepatan waktu yang dibutuhkan untuk mencapai stasiun hanya dengan waktu 30 menit dan setiap 30 menit terdapat kereta yang berhenti di tiap stasiun dan karena mempunyai jalur sendiri membuat ARS terhindar dari kemacetan ibu kota Jakarta.

Di Indonesia sendiri tercatat pada tanggal 2 Maret 2020 merupakan awal dari menyebarnya pandemi virus ini dengan terkonfirmasi terdapat 2 kasus positif COVID-19. Terhitung mulai dari tanggal 2 Maret 2020 itu hingga pada 29 Mei 2020 terkait pandemic virus ini dengan jumlah 91 hari, Pemerintah Indonesia telah menyatakan bahwa keadaan ini terkategori status darurat bencana.membuat Indonesia juga mengalami dampak akibat virus itu juga menyebar di sini sehingga membuat pemerintah mengeluarkan Pembatasan Sosial Berskala Besar dan New Normal yang membuat gerakan Social Distancing.

Kebijakan pembatasan ini mempengaruhi salah satu aspek penting yaitu pembatasan penumpang transportasi. Batasan ini berlaku di semua jenis moda transportasi dengan cara pembatasan jumlah penumpangnya untuk menghindari kontak fisik antar satu sama lain. Untuk itu protokol kesehatan yang diberlakukan harus dilaksanakan untuk semua transportasi baik itu darat, udara, maupun laut. Transportasi Kereta Api Bandara memberlakukan protokol kesehatan seperti tempat duduk yang di beri tanda silang agar tidak ditempati untuk memberi jarak antar pengguna moda transportasi dan protokol lainnya seperti pengecekkan suhu tubuh, penggunaan masker dan lain - lain.

Batasan masalah dalam penelitian ini antara lain:

1. Perilaku dari penumpang yang menggunakan transportasi umum KA Bandara.

2. Persepsi masyarakat terhadap regulasi yang diberlakukan pemerintah pada masa pandemi ini dengan menerapkan Pembatasan Sosial Berskala Besar dan New Normal terhadap pola pelayanan di KA Bandara.

3. Penerapan protokol kesehatan yang diterapkan baik pada penumpang maupun petugas kereta yang bertugas di masa New Normal.

Rumusan masalah yang akan dibahas pada penelitian ini adalah:

1. Bagaimana regulasi yang berlaku dalam mengatur moda transportasi khususnya Kereta Api Bandara pada pemberlakuan Pembatasan Sosial Berskala Besar dan New Normal dalam masa pandemi ini?

2. Bagaimana timbal balik yang dilakukan PT. Railink yang di laksanakan oleh petugas dalam menerapkan regulasi - regulasi yang berlaku untuk penumpang Kereta Api Bandara?

3. Bagaiman persepsi dari masyarakat selaku penumpang dalam menggunakan moda transportasi Kereta Api Bandara yang melaksanakan mengenai regulasi - regulasi yang di dalam stasiun maupun kereta?

4. Apakah kebijakan - kebijakan Pembatasan Sosial Berskala Besar dan New Normal yang berlaku pada masa pandemi wabah virus Covid-19 dalam Kereta Api Bandara berpengaruh terhadap jumlah perjalanan transportasi yang dilakukan masyarakat?

Tujuan dari penelitian ini adalah:

1. Mengetahui apa saja regulasi dan kebijakan yang diberlakukan oleh Pemerintah Indonesia dalam mengatur moda trasnportasi umum khususnya transportasi Kereta Api Bandara pada pemberlakuan Pembatasan Sosial Berskala Besar dan New Normal.

2. Mengetahui respon timbal balik yang dilakukan PT. Railink yang dilaksanakan oleh petugas dalam menerapkan regulasi - regulasi yang berlaku untuk penumpang Kereta Api Bandara.

3. Mengidentifikasi mengenai persepsi dari masyarakat selaku penumpang dalam menggunakan moda transportasi Kereta Api Bandara mengenai regulasi yang di dalam stasiun maupun kereta

4. Mengetahui apakah kebijakan Pembatasan Sosial Berskala Besar dan New Normal yang berlaku pada masa pandemi wabah virus Covid-19 dalam Kereta Api Bandara berpengaruh terhadap jumlah perjalanan transportasi yang dilakukan masyarakat.

\section{Transportasi}

Transportasi adalah memindahkan barang (commodity of goods) dan penumpang dari suatu tempat ke tempat lain, sehingga pengangkut menghasilkan jasa angkutan atau produksi jasa bagi masyarakat yang membutuhkan untuk pemindahan atau pengiriman barang-barangnya menurut (Soegijatna Tjakranegara, 1996). Penyediaan fasilitas yang mendukung pergerakan yang cepat, aman, nyaman dan sesuai kebutuhan akan kapasitas angkut dengan menyesuaikan dengan jenis moda yang digunakan. 


\section{PT. Railink}

Kereta api bandara atau Airport Railink Services (ARS) yang dioperasika oleh PT Railink merupakan hasil kerja sama (joint venture) antara dua BUMN, yaitu PT Kereta Api Indonesia dan PT Angkasa Pura II dimana kedua-duanya merupakan Persero. Kegiatan usaha yang dijalankan oleh PT. Railink yakni pengoperasian, pengelolaan dan pengusahaan kereta api bandara, pengembangan dan pengelolaan stasiun kereta api di bandara dan di pusat kota, pengadaan dan pemeliharaan sarana dan prasarana kereta api, pembangunan prasarana kereta api, konsultasi dan desain sistem perkeretaapian, dan pengusahaan jasa lainnya yang menunjang usaha-usaha pokok

\section{Pandemi wabah virus corona (COVID-19) di Indonesia}

Kasus positif COVID-19 di Indonesia pertama kali dideteksi ketika dua orang warga Indonesia terkonfirmasi tertular dari seorang warga negara Jepang pada 2 Maret 2020. Pada 9 April, pandemic sudah menyebar ke 34 provinsi dengan DKI Jakarta, Jawa Timur, dan Jawa Tengah sebagai provinsi paling terpapar.

Sampai tanggal 17 September 2020, Indonesia telah melaporkan 232.628 kasus positif, kedua terbanyak di Asia Tenggara setelah Filipina. Dalam hal angka kematian, Indonesia menempati peringkat ketiga terbanyak di Asia dengan 9.222 kematian. Namun dengan tidak terhitungnya kasus kematian dengan gejala COVID-19 akut yang belum dikonfirmasi atau dites, diperkirakan angka kematian jauh lebih tinggi dari data yang dilaporkan. Sementara itu, diumumkan 166.686 orang telah sembuh, menyisakan 56.720 kasus yang sedang dirawat.

Pemerintah Indonesia telah menguji 1.652.324 orang dari total 269 juta penduduk, yang ebrarti hanya sekitar 6.129 orang per satu juta penduduk. Sebgai tanggapan terhadap pandemi, beberapa wilayah telah memberlakukan pembatasan sosial berskala besar (PSBB) dan sebagian wilayah tersebut mulai menerapkan kenormalan baru setelah mengakhiri masa PSBB

\section{Kebijakan yang diberlakukan Menhub dan PT. Railink}

Tepat sehari sebelum masa berlaku Surat Edaran Gugus Tugas No. 4 Tahun 2020 habis, Gugus Tugas kembali menerbitkan Surat Edaran Gugus Tugas No. 7 Tahun 2020 tentang Kriteria dan Persyaratan Perjalanan Orang dalam Masa Adaptasi Kebiasaan Baru Menuju Masyarakat Produktif dan Aman Corona Virus Disease 2019 (COVID-19). SE ini merupakan salah satu bentuk dari arah kebijakan menuju era new normal demi membangkitkan atau memulihkan roda perekonomian yang kesiapannya pun hingga saat ini diperdebatkan oleh berbagai pihak. Dalam SE ini disyaratkan kemampuan untuk menunjukan identitas diri, surat keterangan uji PCR dengan hasil negatif yang berlaku 7 hari atau surat keterangan uji Rapid Test dengan hasil non reaktif yang berlaku hanya 3 hari pada saat keberangkatan serta surat keterangan bebas gejala seperti influenza yang dikeluarkan oleh Dokter Rumah Sakit / Puskesmas yang tidak memiliki fasilitas Tes PCR dan/atau Rapid Test (Sofie Wasiat, 2020, Perjalanan Kebijakan Transportasi selama Masa Pandemi Covid 19 - kumparan.com. Diakses 12 September 2020).

Masyarakat yang ingin menggunakan kereta bandara wajib memenuhi 6 persyaratan dari operator, PT. Railink. Bila tidak siap-siap ditolak menggunakan moda transportasi tersebut, yang rencananya akan Kembali beroperasi 1 Juli pasca disetop sementara dalam rangka mencegah penyebaran COVID-19. Pada tahap awal, PT. Railink hanya menjual tiket $70 \%$ dari total kapasitas tempat duduk yang tersedia. Itu dilakukan untuk menjaga physical distancing selama perjalanan. Tiket dapat dipesan secara online melalui aplikasi Railink, website, mitra Railink maupun secara offline di mesin tiket dan Point Of Sales (POS) masing-masing stasiun (Fajar WH, 2020, Tata Cara Menumpang Kereta Bandara Soekarno-Hatta di Masa Adaptasi Normal Baru | Indonesia.go.id. Diakses 20 September 2020).

Berikut ini syarat yang harus dipatuhi para calon penumpang:

1. Wajib menggunakan masker saat berada di area stasiun maupun di dalam perjalanan Kereta Api Bandara.

2. Wajib menjaga jarak minimal satu (1) meter atau mengikuti tanda/marka yang tersedia dengan penumpang lainnya atau petugas.

3. Penumpang dengan suhu tubuh lebih dari $37,3^{\circ} \mathrm{C}$ tidak diperkenankan naik Kereta Api Bandara.

4. Untuk menghindari kontak fisik, disarankan membeli tiket Kereta Api Bandara secara online melalui website, aplikasi Railink, maupun mitra Railink.

5. Menerapkan pola hidup bersih dan sehat, rutin cuci tangan, tidak meludah, buang sampah pada tempatnya, dan hindari menyentuh wajah.

6. Lapor ke petugas jika merasa dan tidak sehat dan apabila calon penumpang/penumpang tersebut memiliki gejalan mirip COVID-19 maka dianjurkan segera menghubungi nomor layanan COVID-19 di 112, 081-112112-112 dan 081-388-376-955 (Dinas Kesehatan Provinsi DKI Jakarta). 


\section{METODE PENELITIAN}

\section{Diagram Alir Penelitian}

Alur atau tahapan dari penelitian ini tertera dalam bentuk diagram pada gambar 1 sebagai berikut.

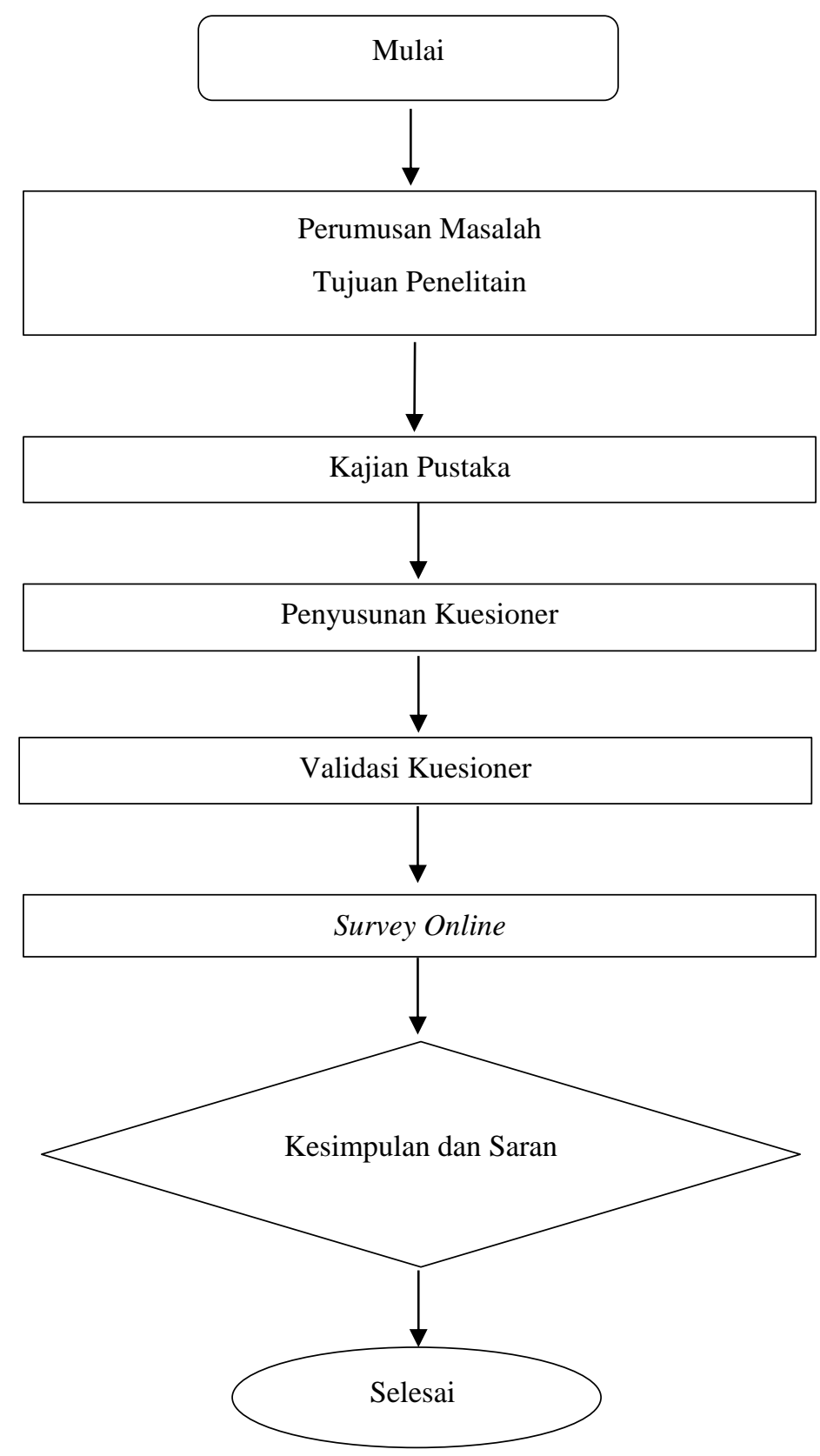

Gambar 1. Diagram alir tahapan penelitian

\section{Jenis penelitian}

Penelitian yang dilakukan berlokasi di Stasiun Manggarai, yang diselenggarakan oleh PT. Railink. KA Bandara yang lewat di jalur KRL Commuter line menuju stasiun Bandara Soekarno Hatta di stasiun. Survey online dilakukan kepada konsumen KA Bandara mengenai perilaku penumpang dan operator dalam mematuhi protokol kesehatan di masa pandemi Covid-19. Survei dilakukan pada saat jam sibuk. 


\section{Responden dan objek studi}

Responden dan Objek Studi dalam analisis penulis adalah konsumen umum KA Bandara yang sudah naik/turun dari KA Bandara. Semua objek studi yang akan diwawancara online diharapkan dapat memberikan respon dan jawaban yang jujur sehingga penelitian ini menjadi valid dan keaslian jawabannya dapat dipertanggungjawabkan. Untuk para konsumen dibedakan dari segi jenis kelamin, usia, pekerjaan yang di bebankan, pada frekuensi menggunakan KA Bandara, keamanan bagi pengguna KA Bandara dan operator, penghasilan yang dimiliki konsumen, dan persepsi terhadap protokol kesehatan ataupun kebijakan lainnya yang diterapkan oleh PT. Railink menurut para konsumen yang menggunakan moda transportasi di dalam kegiatan sehari-hari.

\section{Metode pengumpulan data}

Metode pengumpulan data yang digunakan dalam penelitian ini adalah dalam bentuk kuisioner. Kuesioner merupakan sejumlah pertanyaan atau pernyataan tertulis tentang data faktual atau opini yang berkaitan dengan diri responden, yang dianggap fakta atau kebenaran yang diketahui dan perlu dijawab oleh responden (Sutoyo). Penulis menyebarkan kuisioner survey secara tidak langsung di lapangan, untuk mengetahui dan menuliskan bagaimana pendapat konsumen dari persepsi penumpang maupun operator petugas yang bertugas di kereta api bandara. Hal lain yang dituliskan dan dilakukan analisis identifikasi adalah persepsi penumpang maupun operator petugas dengan pemberlakuan kebijakan protkol kesehatan pada masa pandemic terhadap perjalanan transportasi. Kemudian wawancara yang dilakukan diharapkan kepada konsumen yang terpercaya agar penelitian ini bersifat valid.

\section{Metode analisis data}

Saat melakukan analisis, penulis menerapkan Teori Analisis Normatif dalam menyusun analisis datanya dari desain penelitian yang telah dirancang kuisioner, maka didapatkan persepsi perilaku masing - masing dari penumpang khususnya juga dari sisi pihak PT. Railink. Masing-masing paparan persepsi yang didapat dilakukan analisis melalui penumpang terhadap kebijakan-kebijakan dan peraturan yang sudah diberlakukan mengenai kesehatan, apakah sudah sesuai dengan praktik di lapangan. Melalui persepsi pendapat yang sudah dipaparkan dari penerapan kebijakan dari penumpang itu sendiri maupun petugas yang bertugas dapat dibuat penilaian secara subjektif seberapa terealisasi kebijakan - kebijakan yang diberlakukan dari badan WHO dan di adaptasi kembali sesuai di negara Indonesia oleh Menhub dan Kemenkes.

Setelah itu dilakukan analisis hasil kuisioner terhadap persepsi pendapat dengan faktual yang terjadi dengan cara pendeskripsian menggunakan metode analisis deskriptif dan dibuat kesimpulan mengenai apa yang seharusnya dilakukan mengenai kebijakan yang diberlakukan ini. Dari tiap pendapat persepsi dan saran serta masukan yang telah dipaparkan dilakukan analisis kembali untuk dipilih yang sesuai dengan Analisis Normatif dan Analisis Deskriptif agar didapatkan hasil yang ideal bagi semua pihak dan di evaluasi. Hasil evaluasi yang didapatkan akan mempresentasikan hasil publik terhadap kebijakan yang berlaku khususnya pada Kereta Api Bandara.

\section{HASIL DAN PEMBAHASAN}

\section{Data responden}

Data yang disurvei melalui Daring (Dalam Jaringan) melalui Google Forms awalnya direncanakan untuk 100 responden, namun hasil responden yang didapat adalah 102 responden dengan beragam hasilnya.

Pada pembagian pertama yaitu mengenai tingkat kewaspadaan penumpang KA Bandara di tabel 1. 
Tabel 1. Tingkat kewaspadaan penumpang kereta api bandara

\begin{tabular}{|c|c|c|}
\hline Kriteria & Iya & Tidak \\
\hline \multicolumn{3}{|l|}{ Menuju Stasiun Keberangkatan } \\
\hline $\begin{array}{l}\text { Melakukan Sterilisasi Tempat Duduk yang dilakukan saat } \\
\text { Menggunakan Angkutan Online/Umum }\end{array}$ & 40,2 & 59,8 \\
\hline $\begin{array}{l}\text { Mematuhi Protokol Kesehatan Saat Berada di Angkutan Online } \\
\text { / Umum }\end{array}$ & 100 & 0 \\
\hline $\begin{array}{l}\text { Sterilisasi pada Diri Sendiri setelah Turun dari Angkutan } \\
\text { Online / Umum }\end{array}$ & 64,7 & 35,3 \\
\hline \multicolumn{3}{|l|}{ Saat di Stasiun Keberangkatan } \\
\hline $\begin{array}{l}\text { Terkait Memakai Masker - Face Shield Ketika Memasuki } \\
\text { Stasiun }\end{array}$ & 100 & 0 \\
\hline Melakukan Aktivitas Jaga Jarak & 100 & 0 \\
\hline $\begin{array}{l}\text { Melakukan Sterilisasi Diri Setelah Melakukan Aktivitas } \\
\text { Membeli Tiket }\end{array}$ & 73,5 & 26,5 \\
\hline \multicolumn{3}{|l|}{ Ketika Perjalanan Saat di Dalam Kereta } \\
\hline $\begin{array}{l}\text { Penggunaan Perlengkapan Protokol Kesehatan saat didalam } \\
\text { Kereta }\end{array}$ & 100 & 0 \\
\hline $\begin{array}{l}\text { Duduk di Tempat Duduk yang Hanya di Sediakan oleh Pihak } \\
\text { Stasiun Saat didalam Kereta }\end{array}$ & 100 & 0 \\
\hline $\begin{array}{l}\text { Menjaga Jarak saat Mengantri Masuk ke dalam Kereta dan } \\
\text { didalam Kereta }\end{array}$ & 100 & 0 \\
\hline $\begin{array}{l}\text { Penggunaan Fasilitas Handphone atau Smartphone Selama } \\
\text { Perjalanan }\end{array}$ & 88,2 & 11,8 \\
\hline \multicolumn{3}{|l|}{ Saat di Stasiun Tujuan } \\
\hline Melakukan Aktivitas Jaga Jarak di Stasiun Akhir Tujuan & 100 & 0 \\
\hline Melakukan Pensterilan Diri Sendiri & 73,5 & 26,5 \\
\hline Rata - rata & 86,7 & 13,3 \\
\hline
\end{tabular}


Pada pembagian kedua merupakan tingkat realisasi fasilitas yang dilakukan oleh operator KA Bandara yang disajikan pada tabel 2.

Tabel 2. Tingkat realisasi fasilitas di dalam stasiun dan kereta api bandara

\begin{tabular}{|c|c|c|}
\hline Kriteria & Iya & Tidak \\
\hline \multicolumn{3}{|l|}{ Saat di Stasiun Keberangkatan dan Tujuan } \\
\hline Fasilitas Wastafel yang Memadai di Stasiun Tersebut & 93,1 & 6,9 \\
\hline Berfungsi dengan Baiknya Wastafel di Stasiun Tersebut & 93,1 & 6,9 \\
\hline $\begin{array}{l}\text { Mencukupinya Fasilitas Sabun Cuci Tangan Pada Wastafel di } \\
\text { Stasiun }\end{array}$ & 86,3 & 13,7 \\
\hline Fasilitas Hand Sanitizer di Stasiun & 83,3 & 16,7 \\
\hline Kecukupan Fasilitas Hand Sanitizer di Stasiun & 70,6 & 29,4 \\
\hline $\begin{array}{l}\text { Himbauan untuk Tetap Melaksanakan Protokol Kesehatan } \\
\text { dalam Mengatasi Bahaya Covid-19 dari Banner - Flyer - } \\
\text { Pengumuman Suara atau Video didalam Stasiun }\end{array}$ & 88,2 & 11,8 \\
\hline \multicolumn{3}{|l|}{ Saat di Dalam Rangkaian KA Bandara } \\
\hline $\begin{array}{l}\text { Pembatasan Tempat Duduk yang Sudah diatur Sesuai dengan } \\
\text { Batas Kapasitas yang diberlakukan oleh Pihak PT. Railink } \\
\text { Menurut Kebijakan Kemenkes dan Kemenhub }\end{array}$ & 100 & 0 \\
\hline Fasilitas Hand Sanitizer pada Kereta yang digunakan & 74,5 & 25,5 \\
\hline $\begin{array}{l}\text { Himbauan untuk Tetap Melaksanakan Protokol Kesehatan } \\
\text { dalam Mengatasi Bahaya Covid-19 dari Banner - Flyer - } \\
\text { Pengumuman Suara atau Video didalam Kereta }\end{array}$ & 89,2 & 10,8 \\
\hline \multicolumn{3}{|l|}{ Saat di Stasiun Keberangkatan dan Tujuan } \\
\hline Fasilitas Wastafel dan Hand Sanitizer & 94,1 & 5,9 \\
\hline Tindakan Sterilisasi pada Kereta yang Anda Naikki & 64,7 & 35,3 \\
\hline $\begin{array}{l}\text { Himbauan untuk Tetap Melaksanakan Protokol Kesehatan } \\
\text { dalam Mengatasi Bahaya Covid-19 dari Banner - Flyer - } \\
\text { Pengumuman Suara atau Video didalam Stasiun }\end{array}$ & 88,2 & 11,8 \\
\hline Rata - rata & 85,4 & 14,6 \\
\hline
\end{tabular}


Pada pembagian ketiga merupakan tingkat realisasi pengaturan yang ditegakkanoleh petugas KA Bandara yang disajikan pada tabel 3 .

Tabel 3. Tingkat realisasi pengaturan oleh petugas kereta api bandara

\begin{tabular}{lcc}
\hline \multicolumn{1}{c}{ Kriteria } & Iya & Tidak \\
\hline $\begin{array}{l}\text { Pemeriksaan Suhu Tubuh oleh Petugas } \\
\text { Penganjuran Penumpang untuk Saling Menjaga Jarak oleh }\end{array}$ & 100 & 0 \\
$\begin{array}{l}\text { Petugas } \\
\text { Peneguran Penumpang yang Melanggar Protokol Kesehatan } \\
\text { oleh Petugas }\end{array}$ & 73,5 & 26,5 \\
$\begin{array}{l}\text { Pengarahan Pergerakkan Penumpang pada Area Stasiun yang } \\
\text { Terjadi Penumpukkan Penumpang oleh Petugas }\end{array}$ & 71,6 & 28,4 \\
$\begin{array}{l}\text { Pengarahan Penumpang oleh Petugas untuk Duduk Sesuai } \\
\text { dengan Tempat yang disediakan }\end{array}$ & 100 & 0 \\
\hline Rata - rata & 87,6 & 12,4 \\
\hline
\end{tabular}

\section{Analisis pola perjalanan}

Dalam analisis pola perjalanan penumpang KA Bandara MRI - BST, penelitian ini melakukan pembatasan cakupan aspek perubahan pada pola perjalanan hanya berdasarkan pada kebijakan - kebijakan yang ditetapakan oleh pemerintah pusat khususnya yang berpengaruh baik langsung maupun tidak langsung. Pengaruh kebijakan tersebut dapat dilihat pada pembatasan yang diterapkan pada pembatasan terhadap kapasitas angkut dari rangkaian KA Bandara, pembatasan jadwal jam operasional KA Bandara, pembatasan usia penumpang yang menaiki KA Bandara, serta kebijakan mengenai Work From Home (WFH). Kebijakan Work From Home sendiri dapat berbentuk pembatasan hari kerja pada para pekerja dalam seminggu, pembatasan jam kerja dalam satu hari, serta pembatasan jumlah pekerja di tempat kerja dalam satu waktu.

Analisis pola perjalanan ditinjau berdasarkan aspek keamanan dan kenyamanan penggunaan KA Bandara dan juga kebijakan pemerintah yang dianjurkan khususnya mengenai Work From Home.

\section{Keamanan dan kenyaman}

Berdasarkan paparan sudut pandang penumpang KA Bandara MRI - BST merasa sudah cukup aman dan nyaman untuk melakukan perjalanan transportasi dengan KA Bandara MRI - BST khususnya pada lintas Manggarai - Bandara Soekarno-Hatta, namun tidak dapat dihindarkan ada beberapa responden yang menyatakan tetap merasa kurang bahkan tidak aman dan nyaman dalam melakukan perjalanan transportasi. Berdasarkan tanggapan responden didapat $\geq 70 \%$ penumpang KA Bandara MRI - BST merasa dengan adanya kebijakan - kebijakan yang ada pada masa pandemi ini berpengaruh terhadap perjalanan transportasinya, beberapa di antaranya menyebutkan bahwa menjadi lebih hati-hati dan waspada lagi terhadap sekitar, serta melakukan banyak persiapan untuk melakukan suatu perjalanan untuk mengurangi resiko terdampak Covid-19.

\section{Kebijakan pemerintah}

Dalam analisis pola perjalanan penumpang KA Bandara, penelitian ini membatasi cakupan aspek perubahan hanya berdasarkan pada kebijakan-kebijakan yang dikeluarkan oleh pemerintah yang berpengaruh baik langsung maupun tidak. Pengaruh kebijakan tersebut dapat dilihat pada pembatasan kapasitas angkut rangkaian KA Bandara, pembatasan jam operasional, pembatasan usia penumpang, serta kebijakan Work From Home (WFH). Kebijakan WFH dapat berbentuk pembatasan hari kerja dalam seminggu, pembatasan jam kerja dalam 1 hari, serta pembatasan jumlah pekerja di tempat kerja dalam satu waktu. Dengan berpengaruhnya kebijakan - kebijakan yang ada pada masa pandemi ini terhadap perjalanan transportasi penumpang KA Bandara, didapat sebanyak 77 responden memilih untuk melakukan pembatasan terhadap kegiatan luar, 12 responden memilih tetap melakukan kegiatan luar dengan merubah waktu keberangkatan yang digunakan dari yang biasanya, dan sebanyak 13 responden memilih untuk membatalkan segala kegiatan luar. 
Dari sudut pandang penumpang KA Bandara selaku responden pada penelitian ini, dapat dikatakan PT. Railink sudah cukup baik menerapkan protokol kesehatan yang dianjurkan apabila ingin menggunakan transportasi umum KA Bandara dengan mengaplikasikan sesuai dari kebijakan Kemenkes dan Permenhub yang diadaptasi dari World Health Organization (WHO). Dari sudut pandang penumpang KA Bandara juga menyatakan penumpang yang menggunakan KA Bandara dinilai sudah sadar terhadap kesehatannya masing - masing dan juga lingkungan sekitarnya, dengan taat mengaplikasikan protokol kesehatan yang dianjurkan untuk melakukan perjalanan transportasi

\section{KESIMPULAN DAN DARAN}

\section{Kesimpulan}

Berdasarkan penelitian yang telah dilakukan dapat disimpulkan sebagai berikut:

1. Pada tingkat kewaspadaan responden pengguna KA Bandara lintas Manggarai - Bandara Soekarno-Hatta didapat sebagai berikut:

a. Untuk persiapan dari rumah, hal - hal yang sering kali disiapkan oleh pengguna KA Bandara pada masa pandemi Covid-19 ialah dengan menggunakan masker dan masing-masing membawa sendiri hand sanitizer.

b. Saat perjalanan menuju stasiun keberangkatan, responden umumnya tidak melakukan sterilisasi pada angkutan yang ditumpanginya, namun setelah selesai menumpang responden melakukan tindakan sterilisasi diri.

c. Seluruh responden mematuhi protokol kesehatan di angkutan yang ditumpanginya untuk menuju stasiun keberangkatan.

d. Saat di stasiun keberangkatan, perjalanan dengan KA Bandara, dan saat di stasiun tujuan, penggunaan KA Bandara rata-rata mematuhi protokol kesehatan yang diperlukan dalam melakukan perjalanan, seperti menggunakan masker dan perlengkapan perlindungan diri lainnya, melakukan aktivitas jaga jarak, dan melakukan tindakan sterilisasi baik dengan mencuci tangan atau dengan menggunakan handsanitizer.

e. Penumpang KA Bandara sebanyak 45,1\% melakukan aktivitas berupa bermain game/mendengarkan musik di handphone pada saat menunggu di dalam area stasiun.

f. Ada sebanyak 53,9\% penumpang KA Bandara melakukan aktivitas berupa bermain game/mendengarkan musik selama perjalanannya dengan KA Bandara.

g. Mayoritas penumpang KA Bandara juga menyatakan bahwa $86.7 \%$ rata- rata penumpang sudah awas dan waspada untuk menerapkan protokol kesehatan pada dirinya sesuai dengan arahan Menhub dan Kemenkes yang diadaptasi dari regulasi World Health Organization (WHO).

h. Mayoritas penumpang KA Bandara menyatakan bahwa $85.4 \%$ rata - rata penerapan kebijakan - kebijakan protokol kesehatan dalam transportasi yang diaplikasikan oleh PT. Railink khususnya mengenai fasilitas yang dihadirkan sudah terealisasikan sesuai dengan arahan Menhub dan Kemenkes yang diadaptasi dari regulasi World Health Organization (WHO).

i. Mayoritas penumpang KA Bandara juga menyatakan $87,6 \%$ rata - rata petugasnya sudah merealisasikan pengaturan yang semestinya dilakukan dan ditegakkan sesuai dengan arahan Menhub dan Kemenkes yang diadaptasi dari regulasi World Health Organization (WHO).

j. Ada sebanyak 64,7\% penumpang KA Bandara mengetahui adanya tindakan sterilisasi dan pembersihan lainnya pada rangkaian kereta yang dinaiki.

2. Pada tingkat keamanan, kenyamanan dan pengaruh terhadap pengguna transportasi KA Bandara

a. Penumpang KA Bandara didominasi oleh pernyataan setuju terkait rasa aman dan terlindungi dari rumah sampai stasiun keberangkatan, saat di stasiun keberangkatan, saat perjalanan di kereta, saat tiba di stasiun tujuan.

b. Dominan penumpang KA Bandara menjawab bahwa akan segera melapor secara mandiri ataupun menunggu panggilan dari pihak PT. Railink apabila seandainya terdapat laporan hasil positif kasus reaktif Covid-19 pada jadwal keberangkatannya, guna untuk melakukan tracing (penelurusan) yang dilakukan oleh PT. Railink.

c. Kebanyakan penumpang KA Bandara menyatakan dengan adanya kebijakan-kebijakan dan regulasi yang berlaku pada masa pandemi khususnya terhadap perjalanan transportasinya jadi berpengaruh.

3. Pengaruh yang dirasakan pada umumnya adalah jadi lebih banyak hal yang dilakukan untuk mempersiapkan suatu perjalanan, juga kebanyakan berimbas untuk membatasi kegiatannya di luar.

4. Mengenai anjuran pemerintah soal Work From Home, keinginan penumpang KA Bandara di dominasi oleh pernyataan setuju. 


\section{Saran pemanfaatan penelitian}

Berdasarkan penelitian yang sudah dilakukan dapat direkomendasikan saran terhadap pemanfaatan penelitian, yakni:

1. Dapat diketahui bahwa pelayanan dari pihak operator PT. Railink khususnya pada masa pandemi Covid-19 ini sudah baik, seluruh aturan regulasi yang berlaku pada aktivitas bertransportasi direalisasikan cukup merata pada lintar Manggarai - Bandara Soekarno-Hatta. Harapannya ialah agar pihak operator dapat tetap mempertahankan pelayanannya dan ditingkatkan lagi fasilitas yang tersedia.

2. Penelitian ini dilakukan saat pandemi Coronavirus sedang terjadi di Indonesia, karena terjadi keterbatasan untuk mendapatkan hasil data kuesioner yang menyebabkan kami melakukan hasil Survey Online / Daring sehingga data hasil kuesioner yang di dapatkan tidak dapat maksimal dan tingkat validasinya cukup kurang, serta kurang ditanggapinya link survey ini yang menjadi salah satu permasalahan karena kurang terwakilinya data dari pengisian kuesioner.

\section{DAFTAR PUSTAKA}

Fajar WH, 2020, Tata Cara Menumpang Kereta Bandara Soekarno-Hatta di Masa Adaptasi Normal Baru | Indonesia.go.id. Diakses 20 September 2020

Kumparan.com/kumparanbisnis/sederet-perusahaan-terapkan-kerja-dari-rumah-untuk-cegah-corona-1t2BWqJKK1r. Diakses pada tanggal 12 September 2020

Sofie Wasiat, 2020, Perjalanan Kebijakan Transportasi selama Masa Pandemi Covid 19 - kumparan.com. Diakses 12 September 2020

Surat Edaran Gugus Tugas No. 7 Tahun 2020 tentang Kriteria dan Persyaratan Perjalanan Orang dalam Masa Adaptasi Kebiasaan Baru Menuju Masyarakat Produktif dan Aman Corona Virus Disease 2019 (Covid-19)Surat Edaran Menteri Perhubungan No. 11 Tahun 2020

Tjakranegara, S. Hukum Pengangkutan Barang dan Penumpang. Jakarta: Rineka Cipta, 1996. 